Discussion Paper No. 10-043

\title{
Beyond the Mean Gender Wage Gap: Decomposition of Differences in Wage Distributions Using Quantile Regression
}

Anja Heinze

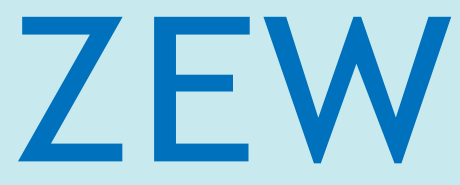

Zentrum für Europäische Wirtschaftsforschung $\mathrm{GmbH}$

Centre for European

Economic Research 
Discussion Paper No. 10-043

\title{
Beyond the Mean Gender Wage Gap: Decomposition of Differences in Wage Distributions Using Quantile Regression
}

\author{
Anja Heinze
}

Download this ZEW Discussion Paper from our ftp server:

ftp://ftp.zew.de/pub/zew-docs/dp/dp10043.pdf

Die Discussion Papers dienen einer möglichst schnellen Verbreitung von neueren Forschungsarbeiten des ZEW. Die Beiträge liegen in alleiniger Verantwortung der Autoren und stellen nicht notwendigerweise die Meinung des ZEW dar.

Discussion Papers are intended to make results of ZEW research promptly available to other economists in order to encourage discussion and suggestions for revisions. The authors are solely responsible for the contents which do not necessarily represent the opinion of the ZEW. 


\section{Non-technical summary}

The fact that women generally earn less than men has stimulated much discussion in industrialized countries since the $1970^{\text {th }}$. Therefore, the level as well as the sources of the gender wage gap are in the focus of the scientific community and are of broad public interest.

The key issue in this study is the extent to which the observed gender wage gap can be explained by individual characteristics such as education and work experience and how much is due to selection into different establishments. Based on a decomposition method, the observed wage gap is assigned to four explanatory components: (1) Difference in the individual characteristics, (2) Difference in the remuneration of these individual characteristics, (3) Difference in establishment characteristics, (4) Difference in the remuneration of these establishment characteristics. Beyond the decomposition of the mean wage gap, the decomposition is undertaken across the entire wage distribution. This study consequently links two aspects of current empirical research on the gender wage gap. On the one hand, the establishment level is included in the study and, on the other hand, the analysis is extended to include the entire wage distribution.

Based on linked employer-employee data the finding is that, on average, women earn 23.5 per cent less than men. The gender wage gap is larger in the lower tail of the wage distribution than on the upper tail. The decomposition of the observed wage gap shows that the four defined decomposition components vary only mildly across the wage distribution. Only a small part of the wage gap is due to differences in the individual characteristics between men and women. In the middle of the wage distribution women are even endowed with better individual characteristics. The segregation of men and women into different firms also explains part of the wage gap, particularly at the lower end of the wage distribution. The largest part of the wage gap is referred to differences in the remuneration of establishment characteristics. It is apparent that even if men and women have the same individual characteristics, receive the same remuneration of these individual characteristics and work in the same firm, women still earn 16 per cent less than men on average. This within-firm wage gap is more pronounced at the lower end of the wage distribution than at the top end.

In summary, the sources of the gender wage gap do not differ much between individuals in the lower and the upper part of the wage distribution. Compared with the selection of men and women into different establishments, differences in qualification between men and women explain only a small part of the observed wage differential. 


\section{Das Wichtigste in Kürze:}

Lohnunterschiede zwischen Männern und Frauen sind seit den 1970er Jahren wiederholt Gegenstand kontroverser Diskussionen in den Industrieländern. Dabei stehen sowohl das Niveau und als auch die Ursachen des geschlechtsspezifischen Lohndifferentials im Mittelpunkt des öffentlichen und wissenschaftlichen Diskurses. Diese Studie geht der Frage nach, wie viel des beobachteten Lohnunterschiedes zwischen Männern und Frauen durch unterschiedlich individuelle Merkmale wie Bildung und Berufserfahrung erklärt werden kann, und wie viel auf die Selektion in unterschiedliche Betriebe zurückzuführen ist. Hierzu wird der beobachtete Lohnunterschied in vier Erklärungskomponenten zerlegt: den Unterschied in individuellen Merkmalen, den Unterschied in der Bewertung dieser individuellen Merkmale, den Unterschied in den Firmenmerkmalen sowie den Unterschied in der Bewertung dieser Firmenmerkmale. Über die Betrachtung des mittleren Lohnunterschieds hinaus wird die Zerlegung über die gesamte Lohnverteilung vorgenommen. Damit verbindet diese Studie zwei Stränge in der aktuellen empirischen Forschung zu geschlechts-spezifischen Lohnunterschieden. Zum einen wird die Betriebsebene in die Untersuchung einbezogen, und zum anderen die Analyse auf die gesamte Lohnverteilung ausgedehnt.

Im Ergebnis zeigt sich, dass Frauen durchschnittlich 23,5\% weniger verdienen als Männer. Am unteren Ende der Lohnverteilung ist der geschlechtsspezifische Lohnunterschied größer als am oberen Rand. Bei der Zerlegung des beobachteten Lohnunterschieds zeigt sich, dass die vier definierten Komponenten nur leicht über die Lohnverteilung schwanken. Auf Unterschiede in den Individualmerkmalen zwischen Männern und Frauen ist nur ein kleiner Teil des Differentials zurückzuführen. Im mittleren Bereich der Lohnverteilung verfügen Frauen sogar über höherwertige Individualmerkmale, wie beispielsweise höhere Bildungsabschlüsse. Die Verteilung von Männern und Frauen auf unterschiedliche Firmen erklärt einen größeren Teil des Lohnunterschiedes, insbesondere am unteren Ende der Lohnverteilung. Der größte Teil des Lohnunterschieds bleibt allerdings unerklärt. Es zeigt sich: Selbst wenn Männer und Frauen über die gleichen individuellen Merkmale verfügen und in den gleichen Firmen arbeiten, verdienen Frauen im Durchschnitt 16 \% weniger als Männer. Dieser inner-betriebliche Lohnunterschied ist am unteren Ende der Lohnverteilung stärker ausgeprägt als am oberen Ende.

Zusammenfassend lässt sich festhalten, dass sich die Ursachen des geschlechtsspezifischen Lohnunterschiedes für geringe und hohe Einkommensgruppen nicht sehr voneinander unterscheiden. Qualifikationsunterschiede zwischen Männern und Frauen erklären im Vergleich zur Selektion von Männern und Frauen in unterschiedliche Firmen nur einen kleinen Teil des beobachteten Lohnunterschieds. Der letztlich unerklärte Lohnunterschied kann zum einen auf Lohndiskriminierung und zum anderen auf unbeobachtete Qualifikations- und Betriebscharakteristika zurückgehen. 


\title{
Beyond the mean gender wage gap: Decomposition of differences in wage distributions using quantile regression
}

\author{
Anja Heinze \\ Centre for European Economic Research (ZEW Mannheim) *
}

\begin{abstract}
Using linked employer-employee data, this study measures and decomposes the differences in the earnings distribution between male and female employees in Germany. I extend the traditional decomposition to disentangle the effect of human capital characteristics and the effect of firm characteristics in explaining the gender wage gap. Furthermore, I implement the decomposition across the whole wage distribution with the method proposed by Machado and Mata (2005). Thereby, I take into account the dependence between the human capital endowment of individuals and workplace characteristics. The selection of women into less successful and productive firms explains a sizeable part of the gap. This selection is more pronounced in the lower part of the wage distribution than in the upper tail. In addition, women also benefit from the success of firms by rent-sharing to a lesser extent than their male colleagues. This is the source of the largest part of the pay gap. Gender differences in human capital endowment as well as differences in returns to human capital are less responsible for the wage differential.
\end{abstract}

JEL Classification: J16, J31

Keywords: gender wage gap, decomposition, quantile regression.

Centre for European Economic Research, Department of Labour Markets, Human Resources and Social Policy, L7.1, 68161 Mannheim, Germany, E-Mail: heinze@zew.de. I would like to thank Michael Burda, Bernd Fitzenberger, Elke Wolf, Melanie Arntz, Alfred Garloff, Karsten Kohn, Thorsten Vogel for valuable comments and discussions. I am grateful to Peter Jacobebbinghaus for help with the data at the Research Data Centre (FDZ) of the Federal Employment Services (BA) at the Institute for Employment Research (IAB), Nuremberg. The institutions mentioned are not responsible for the use of the data in this publication. The financial support by the German Research Foundation (DFG) within the priority program "Potentials for Flexibility in Heterogeneous Labor Markets” (Grant-No. PF 331/3-1) is gratefully acknowledged. 


\section{Motivation}

The gender wage gap has been extensively studied in the labor economics and sociological literature. Even though the pay differential tends to shrink over time, a sizeable gender wage gap persists (see for example, the international evidence in Blau and Kahn, 1996, 2003 and the OECD 2002). Identifying the different source of wage differentials is crucial for explaining and understanding this persistence. In addition, policy options are different depending on the underlying reasons for the wage differentials.

Traditionally, the gap has been explained by gender differences in the human capital endowment and its reward in the labor market. A widely-used way to explore gender wage differentials empirically is to decompose the observed mean gap into a component attributable to differences in human capital characteristics (endowment part) and a component referring to differences in returns to these characteristics (remuneration part). This decomposition into two parts was introduced by Oaxaca (1973) and Blinder (1973).

More recently, gender segregation as a further source of wage differentials has moved more and more into the focus of scholarly interest. The empirical finding is that the segregation of women into low-paying labor market structures is a major source of wage differentials between men and women (e.g. Groshen 1991a, Dolado et al. 2004, Bayard et al. 2003). Although the seminal studies in this field emphasize the importance of female segregation into low-paying occupations (see for an overview Sorensen 1990), more recent studies have extended the analysis to firm segregation and conclude that this segregation is also an important source of gender wage differentials (e.g. Groshen 1991a, Carrington and Troske 1998, Reilly and Wirjanto 1999, Bayard et al. 2003). The importance of firm segregation of men and women is related to empirical findings which point to the influence of labor demandside factors in wage determinations. This empirical literature shows that wage differentials can also be the result of inter-firm wage differentials (overview in Abowd and Kramarz 1999). Thereby the inter-firm wage differentials can be attributed to different reasons, such as compensating wage differentials, efficiency wage payments, institutional settings or rentsharing processes (see for a theoretical overview Groshen 1991b). Since men and women work in different firms, these inter-firm wage differentials can also have an impact on the gender wage gap.

One purpose of this study is to disentangle the effect of differences in personal characteristics and the effect of selection into different firms of women and men on the gender wage gap. For 
this aim, the wage equations include establishment characteristics in addition to individual characteristics and the traditional Oaxaca-Blinder (OB) decomposition is extended.

Another relevant finding in the recent gender wage gap literature is that the gap is very complex and varies across the wage distribution. Albrecht et al. (2003), for instance, detect that while the average gender wage gap is indeed relatively small in Sweden, the gap increases throughout the wage distribution and rises even more in the upper tail. They conclude that the earnings potential of women in the upper part of the wage distribution is limited (glass ceiling effect). Hence, assuming a constant wage gap throughout the wage distribution is misleading because this could wrongly lead us to conclude the gender wage gap to be of minor importance. Furthermore, the traditional approach is based on the assumption that the importance of explanatory factors does not vary with the wage rate. This assumption is not very realistic. Among others, Albrecht et al. (2003) show an increasing impact of education on the wage differential across the wage distribution. In fact, there are many good reasons to believe that male and female wages are also not equally affected by innovative human resource practices and institutional settings across the wage distribution. In particular, firm characteristics describing the collective bargaining and co-determination are supposed to be more important in the wage determination process of employees with low earnings because these workers belong to the main target group of unions. Furthermore, it is conceivable that firm's profits have a stronger impact on the wage rate of highly-paid employees because they are more likely to get corresponding bonus payments.

As an additional contribution, therefore, this study decomposes the gender wage gap across the wage distribution and thus combines two important strands of the recent empirical literature. On the one hand differences in the workplaces of male and female employees are taken into account and on the other hand the analysis is extended to the entire wage distribution. More precisely, I include a detailed set of firm characteristics in addition to individual characteristics as wage determinants. Then in order to decompose the observed wage gap, I apply an extension of the traditional OB decomposition to disentangle the effect of personnel characteristics (including human capital and occupations) and the effect of firm characteristics in explaining the gender wage gap. The extended decomposition results in four terms: one attributable to differences in individual characteristics, one referring to differences in returns to individual characteristics, another that captures differences in firm-specific characteristics and finally one resulting from differences in returns to these characteristics. In order to accommodate differences across the wage distribution, the four decompositions terms 
are implemented at each percentile of the wage distribution. To this end a flexible parametric method introduced by Machado and Mata (2005) is applied.

The empirical analysis is based on a large German linked employer-employee data set. The comparison of the wage information for male and female employees in the sample shows that the raw gender wage gap is sharply decreasing within the first quartile, the decrease then decelerates until the $60^{\text {th }}$ percentile, and after that the gap is slightly increasing again.

The decomposition shows that the selection of women into less successful and productive firms explains a sizeable part of the gap. This selection is more pronounced in the lower part of the wage distribution than in the upper part. In addition, women benefit from the success of firms to a lesser extent than their male colleagues. This is the source of the largest part of the pay gap. Gender differences in individual characteristics as well as differences in returns to these characteristics play a smaller role in explaining the wage differential.

The remainder of the study is organized as follows. Section 2 briefly discusses the literature on decomposing gender wage gaps throughout the wage distribution. The econometric methodology is presented in Section 3. Section 4 describes the data source and the specification of the wage equations. Section 5 presents and discusses the results. Finally Section 6 gives some concluding remarks.

\section{Decomposing the gender wage gap: Some background}

A decomposition analysis is a standard approach to explore the wage differential between male and female employees. It is often used to examine the sources of the gap and to answer the question, how much of the gap is attributable to discrimination. In this approach the mean wage differential is decomposed into one part capturing differences in characteristics and another part referring to different returns using the estimates of male and female wage equations (Oaxaca 1973 and Blinder 1973). The latter part is called the unexplained part of the wage differential or the remuneration effect. This fraction of the gap is often used as a measure of wage discrimination. ${ }^{1}$

However, one drawback of this standard approach by Oaxaca (1973) and Blinder (1973) is the focus on the average gender wage differential. Thus, potentially important variations of the wage differences across the wage distribution are not taken into account. Hence, the

\footnotetext{
${ }^{1}$ However, Altonji and Blank (1999) argue in their survey article "Race and Gender in the Labor Market" that this is a misleading terminology, because if any control variables are omitted that are correlated with the included characteristics, then the coefficients will be affected. The unexplained part therefore captures both the effects of discrimination and unobserved gender differences in productivity and tastes. Furthermore, discriminatory barriers in the labor market can also affect the characteristics (such as education) of individuals.
} 
attention in empirical gender studies has shifted towards investigating the degree to which the gender wage gap varies across the wage distribution. For instance, Fortin and Lemieux (1998) decompose changes in the US gender wage gap at various wage percentiles. They apply rank regressions to estimate the probability of an individual being in a certain wage segment given this individual's characteristics. Bonjour and Gerfin (2001) apply a methodology proposed by Donald et al. (2000) to decompose the gender wage gap across the earnings distributions in Switzerland. The basic idea of the applied method is to recover estimates of the density and distribution functions from the estimated parameters of a hazard function.

Most recently, studies use quantile regressions in order to decompose the gender wage gap at different points of the wage distribution. García et al. (2001) propose to use quantile regressions in order to compare quantiles of the male and the female wage distribution conditional on the same set of characteristics as an approximation of the unexplained part of the gap. However, their decomposition of the Spanish gender wage gap evaluates the vector of characteristics of men and women at only one point, the unconditional mean, regardless of which quantile is considered. Gardeazabal and Ugidos (2005) consider it more suited to weight the difference in returns to a certain characteristic (for example primary education) at a given quantile according to the proportion of individuals with this characteristic at that quantile. Based on this methodological approach, their findings for the Spanish wage gap contradict the results of García et al. (2001). While in the analysis of García et al. (2001) the part of the gender wage gap due to different returns to characteristics increases throughout the wage distribution, Gardeazabal and Ugidos (2005) find the opposite to be the case.

Considering only the mean of the regressors like García et al. (2001) neglects some important factors explaining the difference between the two distributions. Assume, for instance, that the sample means of the characteritics are the same for males and females, but the variance is much higher for males. In this setting, the distribution of the dependent variable will also have a higher variance for males. This feature can not be analyzed with the method suggested by García et al. (2001) or the one used by Gardeazabal and Ugidos (2005). Machado and Mata (2005) (MM) hence propose an alternative decomposition procedure which combines a quantile regression and a bootstrap approach in order to estimate counterfactual density functions. Albrecht et al. (2003) applied this method for the first time to decompose the gender wage gap in Sweden. They show that the gender wage gap in Sweden increases throughout the wage distribution and rises in the upper tail. The authors interpret this as a strong glass ceiling effect. The wage gap also increases throughout the 
wage distribution after controlling for gender differences in individual characteristics. Using the same estimation strategy, De la Rica et al. (2008) show that the gender wage gap in Spain is much flatter than in Sweden. However, if the sample is split according to education, the authors also find a glass ceiling effect for the group of high skilled employees, while the gender wage gap decreases throughout the wage distribution for workers with low education. Albrecht et al. (2009) investigate the gender wage gap in the Netherlands using the MM decomposition method and take into account a selection of women into full time employment. Thus, the authors' purpose is to make statements for all employed women regardless of their hours of work. Also applying the MM decomposition method, Arulampalam et al. (2007) explore the wage differential for eleven European countries. Their results show a u-shaped raw wage gap for the private sector in Germany. However, in the public sector the gender wage gap is smaller and wider at the left hand side. While the unexplained part of wage differential is nearly constant across the wage distribution in the private sector, this part decrease throughout the distribution in the public sector. Beblo et al. (2003) also take into account the whole distribution in their analysis of the gender wage gap in Germany by using the Juhn-Murphy-Pierce (Juhn et al. 1993) decomposition. They pool employees of the public and private sector and find a u-shaped raw wage gap. Furthermore their results show that the part explained by differences in individual characteristics increases throughout the distribution. The part attributable to difference in returns to these characteristics has the reverse pattern. The results of Hübler (2005) differ from Beblo et al. (2003). He considers the gender wage differential over a time period from 1984 to 2002. In his study the raw wage gap decreases with increasing quantiles of the wage distribution. Based on a combination of linear local matching and quantile regressions he shows that the unexplained wage differences between males and females are larger in the higher percentiles of the wage distribution. Furthermore, the difference in the unexplained wage gap between the $10^{\text {th }}$ and $90^{\text {th }}$ percentile narrows over time. Fitzenberger and Kunze (2005) like Hübler (2005) find that the German gender wage gap is highest in the lower part and lowest in the upper part of the distribution. Their study highlights that occupational segregation and lower occupational mobility among females may explain the gender wage gap, a result that differs across the wage distribution. Using the MM decomposition method they show that in the lower part of wage distribution, females benefit less from occupational mobility than males. In the upper tail the gains are similar for both sexes.

My study differs from existing studies in three respects. First, I include a set of detailed establishment characteristics in addition to individual characteristics as explanatory 
variables. Second, I extend the traditional OB decomposition to disentangle the effect of individual characteristics and the effect of establishment characteristics in explaining the mean gender wage gap. Finally, I implement the decomposition across the entire wage distribution with the MM method. Based on this most flexible parametric decomposition, I provide new insights into the nature and the sources of gender wage inequality in Germany.

\section{Methodology}

\subsection{Wage regression}

OLS and most other estimation approaches are used to investigate mean effects. In this framework the effect of covariates operates only as a shift factor. Koenker and Bassett (1978) introduced a more flexible approach, the quantile regression model. This model allows for studying marginal effects of covariates on the dependent variable at various points in the distribution, not just at the mean. There is a comprehensive literature concerning the application of quantile regressions, see Fitzenberger et al. (2001) and Koenker and Hallock (2001) for surveys.

Let $w_{i}$ denote the log wage of worker $i . X_{i}$ is a vector of covariates representing his individual characteristics, whereas $Z_{i}$ represents establishment characteristics. The statistical model specifies the $\theta$ th quantile of the conditional distribution of $w_{i}$ given $X_{i}$ and $Z_{i}$ as a linear function of the covariates,

$$
Q_{\theta}\left(w_{i} \mid X_{i}, Z_{i}\right)=X_{i} \beta_{\theta}+Z_{i} \delta_{\theta}, \quad \theta \in(0,1) .
$$

As shown by Koenker and Bassett (1978), the quantile regression coefficients $\beta_{\theta}$ and $\delta_{\theta}$ are estimated as the solution to the following minimization problem: ${ }^{2}$

$$
\left[\begin{array}{l}
\hat{\beta}_{\theta} \\
\hat{\delta}_{\theta}
\end{array}\right]=\underset{\beta, \delta}{\arg \min }\left[\sum_{i: w_{i} \geq X_{i} \beta+Z_{i} \delta} \theta\left|w_{i}-X_{i} \beta-Z_{i} \delta\right|+\sum_{i: w_{i}<X_{i} \beta+Z_{i} \delta}(1-\theta)\left|w_{i}-X_{i} \beta-Z_{i} \delta\right|\right] .
$$

The estimated quantile regression coefficients, $\hat{\beta}_{\theta}$ and $\hat{\delta}_{\theta}$, are interpreted as the estimated returns to individual and establishment characteristics at the $\theta$ th quantile of the log wage distribution.

Since wages observed in the data are censored from above at the social security taxation threshold $c_{s}$, one observes only $\tilde{w}_{i}=\min \left\{w_{i}, c\right\}$. Powell $(1984,1986)$ developed censored

\footnotetext{
${ }^{2}$ Consistency and asymptotic normality of the estimators can be proved if the minimization problem (2) is transferred into a GMM framework (see e.g. Buchinsky 1998). The asymptotic covariance matrix of the estimator can also be derived from this model framework.
} 
quantile regressions as a robust extension to the censored regression problem. There are different algorithms to solve this non-convex optimization problem in the literature (see e.g. Buchinsky 1994, Koenker and Park 1996 or Fitzenberger 1997a, 1997b). However, as the access to the data ${ }^{3}$ is limited and the sample size is large it is not possible to implement censored quantile regressions. As an alternative, I apply quantile regressions after imputing estimated uncensored wages (see Gartner 2005). As described in the next section, rightcensored observations are replaced by wages randomly drawn from a truncated normal distribution. The predicted wages from a Tobit wage regression are used to construct the moments of this truncated normal distribution. The lower truncation point of the truncated normal distribution is given by the contribution limit of the social security system. In the Tobit regression model, the same exogenous variables are used as in the quantile regression model.

Heteroscedasticity consistent standard errors for the quantile regression estimates can be obtained by means of the design matrix bootstraps (see e.g. Kohn 2006). Again, because of the limited access to the data, I cannot estimate standard errors. Nevertheless the decomposition method applied in this study, still yields valuable insights.

\subsection{Decomposition}

The quantile regression analysis provides detailed insights into the remuneration of observed worker and establishment characteristics for men and women across the whole wage distribution. A decomposition analysis can complement the regression evidence by showing whether differences in observed distributions follow from differences in estimated coefficients or from differences in the composition of the workforce. In an OB decomposition, the gender wage gap is evaluated at the average characteristics of male (m) and female (f) employees: ${ }^{4}$

$$
\bar{w}^{m}-\bar{w}^{f}=\left(\bar{X}^{m}-\bar{X}^{f}\right) \hat{\beta}^{m}+\bar{X}^{f}\left(\hat{\beta}^{m}-\hat{\beta}^{f}\right),
$$

where $\bar{w}^{g}$ is the mean of the log wage for $g=m, f, \bar{X}^{g}$ the vector of average characteristics of male and female employees and $\hat{\beta}^{g}$ the estimated vector of returns to characteristics. The first term on the right hand side of equation (3) represents the part of the

\footnotetext{
${ }^{3}$ The data are only available at the Research Data Centre (FDZ) of the Federal Employment Agency (BA) in Nuremberg. The FDZ offers the possibility to work with the data on site and to send programs to a remote data access. However, the computation time is limited.

${ }^{4}$ The mean gender wage gap in equation (3) is decomposed by adding and simultaneous subtracting a counterfactual wage $\bar{w}^{c}=\bar{X}^{f} \hat{\beta}^{m}$ from the difference between the average male and average female wage.
} 
wage gap due to different characteristics of males and females, whereas the second term is the part attributable to differences in the returns to these characteristics. In order to distinguish between individual characteristics $(X)$ and establishment characteristics $(Z)$ I extend the OB decomposition in the following way:

$$
\bar{w}^{m}-\bar{w}^{f}=\underbrace{\left(\bar{X}^{m}-\bar{X}^{f}\right) \hat{\beta}^{m}}_{(i)}+\underbrace{\bar{X}^{f}\left(\hat{\beta}^{m}-\hat{\beta}^{f}\right)}_{(i i)}+\underbrace{\left(\bar{Z}^{m}-\bar{Z}^{f}\right) \hat{\delta}^{m}}_{(i i i)}+\underbrace{\bar{Z}^{f}\left(\hat{\delta}^{m}-\hat{\delta}^{f}\right)}_{(i v)} .
$$

The first term on the right hand side of equation (4) captures the part of the wage differential that is attributable to differences in individual characteristics (i). The third term shows the component of the wage gap due to differences in the establishment characteristics (iii). The second and the forth term represent the components attributable to differences in the returns to individual characteristics (ii) and to establishment characteristics (iv), respectively. In order to decompose the gender wage gap as in equation (4), I use as counterfactual wage ${ }^{5}$

$$
\bar{w}^{c}=\bar{X}^{f} \hat{\beta}^{m}+\bar{Z}^{f} \hat{\delta}^{m}
$$

that reflects what the log wage would have been had females receive the same returns to characteristics as their male counterparts. The approach assumes that male returns are the relevant benchmark for the distribution in the absence of any "discrimination”. 6

The approach in equation (4) considers only differences in the average earnings. As stated above, the average wage gap is not representative of the gap at different quantiles of the wage distribution. Garcia et al. (2001) combine the OB decomposition technique with quantile regressions to determine the decomposition terms at various points of the wage distribution. They consider the mean of the covariates and quantile regression estimates. Thus differences in higher moments of the distribution of the independent variables are not controlled for. The method proposed by Machado and Mata (2005) can account for such differences. It combines a quantile regression model with a bootstrap approach to simulate counterfactual wage densities. ${ }^{7}$

\footnotetext{
${ }^{5}$ It is well known that the partition depends on the ordering of the effects and that the decomposition results may not be invariant with respect to the choice of the involved counterfactual. See the surveys of Oaxaca and Ransom (1994) and Silber and Weber (1999). Therefore, the choice of a counterfactual should be guided by the questions of economic interest.

${ }^{6}$ Most other studies to the gender wage gap use male returns as benchmark and thus comparisons are possible.

7 The MM method relies on the following ideas. First, the conditional quantiles of $w$ given by equation (1) can be estimated by quantile regressions. Second, the probability integral transformation theorem is used: If $U$ is uniformly distributed on $[0,1]$, then $F^{-1}(U)$ has distribution $F$. Thus, for given $\left[X_{i}: Z_{i}\right]$ and a random $\theta \sim U[0,1], X_{i} \beta_{\theta}+Z_{i} \delta_{\theta}$ has the same distribution as $w_{i} \mid X_{i}, Z_{i}$. If $[X: Z]$ are randomly drawn from the population, instead of keeping $\left[X_{i}: Z_{i}\right]$ fixed, $X \beta_{\theta}+Z \delta_{\theta}$ has the same distribution as $w$ (see also Melly 2005).
} 
In order to save computation time, I apply a simplification of the MM techniques as suggested in Albrecht et al. (2003). Formally, the estimation procedure involves four steps:

1. Estimate quantile regression coefficients at each single percentile for male and female employees: $\left(\begin{array}{c}\hat{\beta}_{\theta}^{m} \\ \hat{\delta}_{\theta}^{m}\end{array}\right),\left(\begin{array}{c}\hat{\beta}_{\theta}^{f} \\ \hat{\delta}_{\theta}^{f}\end{array}\right) ; \theta=0.01 \ldots 0.99$. This results in 99 coefficient vectors for males and 99 coefficient vectors for females.

2. Randomly draw samples of size $M=10000$ with replacement from the set of covariates $[X: Z]$ for each estimated coefficient vector: $\left\{\tilde{X}_{i}^{m}: \tilde{Z}_{i}^{m}\right\}_{i=1}^{M} ;\left\{\tilde{X}_{i}^{f}: \tilde{Z}_{i}^{f}\right\}_{i=1}^{M} ;\left\{\tilde{X}_{i}^{f}: \tilde{Z}_{i}^{m}\right\}_{i=1}^{M}$.

3. Calculate $\left\{\tilde{w}_{i}^{m}=\tilde{X}_{i}^{m} \hat{\beta}_{\theta}^{m}+\tilde{Z}_{i}^{m} \hat{\delta}_{\theta}^{m}\right\}_{i=1}^{M}$ and $\left\{\tilde{w}_{i}^{f}=\tilde{X}_{i}^{f} \hat{\beta}_{\theta}^{f}+\tilde{Z}_{i}^{f} \hat{\delta}_{\theta}^{f}\right\}_{i=1}^{M}$ for each estimated coefficient vector. These data sets are random samples of $M \times 99$ observations from the marginal wage distributions of $w$ which is consistent with the linear model in equation (1).

4. Generate the following random samples of the counterfactual distributions with the estimated coefficients of each percentile:

$\left\{\tilde{w}_{i}^{1}=\tilde{X}_{i}^{f} \hat{\beta}_{\theta}^{m}+\tilde{Z}_{i}^{m} \hat{\delta}_{\theta}^{m}\right\}_{i=1}^{M},\left\{\tilde{w}_{i}^{2}=\tilde{X}_{i}^{f} \hat{\beta}_{\theta}^{f}+\tilde{Z}_{i}^{m} \hat{\delta}_{\theta}^{m}\right\}_{i=1}^{M}$ and $\left\{\tilde{w}_{i}^{3}=\tilde{X}_{i}^{f} \hat{\beta}_{\theta}^{f}+\tilde{Z}_{i}^{f} \hat{\delta}_{\theta}^{m}\right\}_{i=1}^{M}$

$\tilde{w}^{1}$ is the hypothetical log wage for female employees if they had the establishment characteristics of male employees and had been paid as male employees. $\tilde{w}^{2}$ is the hypothetical log wage for female employees if they had the establishment characteristics of male employees and only those characteristics had the same returns as for male employees. Finally, $\tilde{w}^{3}$ denotes the hypothetical log wage for female employees as their establishment characteristics had been rewarded as they are for men.

The empirical implementation of this procedure is, however, not straightforward. In the second step of the estimation procedure above, I have to draw a random sample that contains random draws of women's individual characteristics and men's establishment characteristics. If the characteristics were independent it would be possible to assign the randomly drawn female to any drawn male employee. However, it is not very realistic to assume independency between individual and establishment covariates. In contrast, a self selection of individuals into certain firms is much more likely. Alternatively, employers demand employees with certain skills. In order to incorporate the correlation between 
individual and establishment covariates, I decide for the following assignment strategy guided by the economic meaning behind the counterfactual wage distributions in step 4: First I constitute a random sample of $\mathrm{M}$ female employees. After this I implement a matching on the Mahalanobis distance in order to assign each woman to a similar male worker with respect to individual characteristics. From the matched pairs I consider the individual characteristics from the female employees and the establishment characteristics from the matched male employees.

Based on the estimation results generated by the procedure described above, I can decompose the gender wage gap into the contribution of the individual characteristics and the establishment characteristics as well as the contribution of the returns to individual characteristics and establishment characteristics. In order to simplify the comparison to the OB decomposition, I decompose the quantiles of the wage distribution as follows:

$$
\begin{aligned}
Q_{\theta}\left(w^{m}\right)-Q_{\theta}\left(w^{f}\right) & =\underbrace{\left[Q_{\theta}\left(\tilde{w}^{m}\right)-Q_{\theta}\left(\tilde{w}^{1}\right)\right]}_{(i)}+\underbrace{\left[Q_{\theta}\left(\tilde{w}^{1}\right)-Q_{\theta}\left(\tilde{w}^{2}\right)\right]}_{(i i)} \\
& +\underbrace{\left[Q_{\theta}\left(\tilde{w}^{2}\right)-Q_{\theta}\left(\tilde{w}^{3}\right)\right]}_{(\text {iii })}+\underbrace{\left[Q_{\theta}\left(\tilde{w}^{3}\right)-Q_{\theta}\left(\tilde{w}^{f}\right)\right]}_{(i v)}+R .
\end{aligned}
$$

In analogy to equation (4) there are four terms and an additional residual term. The first term (i) represents the contribution of individual characteristics and the second term (ii) denotes the contribution of the corresponding coefficients to the difference between the $\theta$ th quantile of the male wage distribution and the $\theta$ th quantile of the female wage distribution. The third term (iii) refers to the contribution of the establishment characteristics and the fourth term (iv) is the contribution of the corresponding coefficients to the difference between $\theta$ th quantile of the male wage distribution and $\theta$ th quantile of the female wage distribution. The last term is a residual term in equation (6). It includes sampling errors which disappear with more observations, simulation errors which disappear with more simulations and specification errors by estimating a linear quantile regression. Assuming that my specification is correct, the residual term asymptotically tends to zero and equation (6) describes the true decomposition of the gender wage gap in quantiles.

Note that the first and third terms do not have exactly the same meaning as in the case of an OB decomposition due to the previously described assignment strategy. As an example, the counterfactual log wage $\tilde{w}^{1}$ for women is only based on the establishment characteristics of men with comparable individual characteristics. Thus, if there is no overlap between certain parts of the male and the female sample with respect to individual characteristics, the establishment characteristics of the corresponding male sub-sample is not used for the 
counterfactual female wage distribution $\tilde{w}^{1}$. As a consequence, the contribution of establishment characteristics to the decomposition part (i) is not necessarily cancelled out, but leaves some unknown residual. Similarly, decomposition part (iii) does not necessarily hold because the counterfactual establishment characteristics for women only refer to men who are comparable with regard to their individual characteristics. In other words, decomposition parts (i) and (iii) do not show the pure contribution of differences in individual characteristics and differences in establishment characteristics of male and female employees, but only hold in approximation. However, if male and female employees are not systematically different, i.e. there is a common support along the whole range of individual characteristics, than this residual effect is zero and term (i) and (iii) hold exactly. ${ }^{8}$

\section{Data and specification}

\subsection{General construction of the data}

The empirical analysis is based on the IAB Linked Employer-Employee panel (LIAB) which combines data from the IAB Establishment Panel and the Employment Statistics Register.

The first data set, the IAB Establishment Panel, is an annual survey of German establishments administered since 1993. ${ }^{9}$ The database is a representative sample of German establishments employing at least one employee who pays social security contributions. During the time of analysis around 84 percent of all employed persons in Germany are covered by the social security system. The survey was administered through personal interviews and provides general information on the establishment, such as investments, revenues, size, composition of the workforce, salaries and wages.

The second data set, the so-called Employment Statistics Register, is an administrative register data set of all employees in Germany paying social security contributions. ${ }^{10}$ In order to comply with legal requirements, employers have to provide information to the social security agencies for all employees who pay social security contributions. Due to its administrative nature, this database provides reliable information on the daily earnings that are subject to social security contributions. Furthermore, the data include information on age, gender, occupation, employment status and education. The date of entry into the establishment and the ending date of the employer's notification are also available in the

\footnotetext{
${ }^{8}$ For my analysis, these residuals turn out to be small when using a random assignment of female individual covariates and male firm characteristics.

${ }^{9}$ Eastern German establishments are surveyed since 1996. Detailed information on the IAB Establishment Panel is given by Kölling (2000).

${ }^{10}$ Information on the Employment Statistics Register is given by Bender et al. (2000).
} 
individual data and are used to calculate job tenure. Note, however, that this tenure variable cannot be corrected for employment breaks as this information is not available. Hence this variable is only a proxy for tenure.

The sample for the subsequent analysis of the linked employer-employee data is constructed in two steps: First, I select establishments from the establishment panel data set for the year 2002. ${ }^{11}$ I exclude firms from eastern Germany and non-profit firms because both the wage level as well as the wage setting process is still different in those firms and would require a separate analysis. Furthermore, I only consider firms with at least 10 employees.

In the second step, the establishment data are merged with the notifications for all employees employed by the selected establishments in 2002. From the worker data, I eliminate foreigners, apprentices, part-time workers and home workers in order to ensure that the dependent and the independent variables are comparable for my sample. I restrict the analysis to employees who are between 25 and 55 years old to avoid inference with ongoing education and early retirement. Since I consider only full-time workers, I also drop those whose wage is less than twice the lower social security contribution limit or have more than one employment. I am aware that by dropping part-time workers I exclude a lot of women from the analysis. However, the data set includes only information on the daily wage rate and no information of working hours. Thus, it is not possible to calculate wage rates per hour. Controlling for the working status by a dummy variable would also lead to improper results because part-time working can comprise a range of three to six hours. For this reason, I decide to limit my analysis to full-time workers. The final sample contains 384,908 male and 98,368 female employees in 3,994 establishments.

The dependent variable in the subsequent analysis is the log real gross daily wage. The wage also contains all fringe benefits that are subject to social security contributions. The reported wage rates are top-coded at the upper contribution limit to the social security system. In the sample, top-coding affects 18.1 percent of all observations. Male employees are more affected by top-coding than female employees. ${ }^{12}$ While in the subsample of male employees the wage is censored above the $81^{\text {st }}$ quantile of the male wage distribution, the censoring of the female wage distribution appears above the $93^{\text {rd }}$ quantile.

To address this problem, a Tobit regression is estimated by gender with log daily wage as the dependent variable. The independent variables are the same individual and establishment covariates as in the decomposition analysis later on. Then, as described in Gartner (2005),

\footnotetext{
${ }^{11}$ From the available waves 1993 to 2003, I use one wave, the year 2002, since the estimation procedure does not allow for more observations.

${ }^{12}$ Top-coding affects 20.6 percent of all men and 8.5 percent of all women.
} 
right-censored observations are replaced by wages randomly drawn from a truncated normal distribution. Predicted values from Tobit wage regressions are used to construct the moments of the truncated normal distribution. The lower truncation point of the distribution is the contribution limit to the social security system.

\subsection{Individual and establishment covariates}

In order to estimate log wage equations, I use a set of individual characteristics and a set of establishment characteristics. Thus both labor supply and labor demand aspects of the wage setting process are taken into account.

The set of individual characteristics should capture the productivity of individuals. These variables include six formal skill dummies, age, age squared, job tenure and six dummies for occupational categories. ${ }^{13}$ Table A1 (in the appendix) presents summary statistics of the individual characteristics used in the subsequent analysis. The summary statistic shows that, on average, male employees are older and have longer job tenures than female employees. Most male and female employees have a vocational training degree, yet the share of men is higher than the share of women. Furthermore, many females do not have any vocational training and the share of women without a degree is higher than the proportion of men. The summary statistic also indicates that most male employees in the sample are blue collar workers, while most female employees work in administrative occupations.

While there are numerous theoretical and empirical studies discussing the effect of human capital variables (see e.g. Mincer 1974, Card 1999), there is no “universally accepted” set of establishment variables that should be included when investigating determinants of wages. However, as there is widespread empirical evidence that different establishments may pay different wages to employees of equal ability (see e.g. Groshen 1991b, Abowd and Kramarz 1999, Cardoso 2000) ${ }^{14}$, I attempt to account for these differences by including establishment characteristics. Motivated by studies which investigate single aspects of establishment wage differentials (for instance employer size or bargaining regime wage differentials), I gather various establishment characteristics as wage determinants. First, I include variables describing the workforce within establishments. These are the number of employees and its square as well as the gender and qualification composition. The positive impact of the

\footnotetext{
${ }^{13}$ Unfortunately, I cannot control for employment interruptions and the actual labor market experience. This could lead to a bias in the estimation, especially for female employees. However, the data set does not include such information.

${ }^{14}$ There is also earlier research on wage differentials that highlighted the relevance of wage policies at the firm level (see the overview by Kerr 1994).
} 
establishment size has been widely discussed in the literature (see for an overview Oi and Idson 1999) which considers the size typically as a proxy for various unobserved determinants such as job satisfaction, monitoring costs, more complex technologies and worker participation in monopoly profits. ${ }^{15}$ Other studies (see e.g. Carrington and Troske 1998, Reilly and Wirjianto 1999, Datta Gupta and Rothstein 2005) stress the negative relationship between the female proportion within establishments and wages. ${ }^{16}$ The effect of the qualification level of the workforce can be explained by sorting theories. According to these, the quality of a worker has an impact on the productivity of his or her co-workers (see, for example, the model of Kremer 1993).

In addition, I take into account establishment characteristics capturing the current profitsituation and the long run profitability. The theory of rent sharing in the labor market predicts that firms generating rents on the product market may share them with their workforce (e.g. Abowd and Lemieux 1993, Blanchflowers et al. 1996). The extent of rent sharing depends on the relative bargaining power of employers and employees. The theory therefore predicts that employees in more profitable firms may earn higher wages than workers in less successful firms. Therefore, I include sales per employee and two dummy variables indicating whether the revenues of the establishment increased or decreased during the last year. Furthermore, the share of exports in total sales is used as a wage determinant. This variable reflects the extent of product market competition under which firms operate. In the literature, there is the hypothesis that exporting renders firms more productive and leads to higher wages (see e.g. Bernard and Wagner 1997, Bernard and Jensen 1999). The reason is that exporting firms are forced to improve faster than firms only operating on the national market due to higher stress of competition. However, the recent theoretical literature (e.g. Melitz 2003) argues that the positive relationship between productivity and exporting is due to a self-selection of more productive firms into foreign markets. The empirical findings of Schank et al. (2010) support this latter argument for Germany. Overall, one would expect a positive relationship between wages and the share of exports in total sales. In order to further control for firm productivity, estimations include a discrete choice variable indicating the state-of-the-art of the production technology used in the establishment.

Furthermore, labor market institutions are taken into account. In Germany the most important institution is collective wage bargaining. A large theoretical and empirical

\footnotetext{
${ }^{15}$ Schmidt and Zimmermann (1991) find that when using all possible controls, wages increase with firm size. They conclude that there have to exist other reasons why large firms are able to pay higher wages and nevertheless survive. A possible explanation might be non-production economics of scale.

${ }^{16}$ In the next chapter I investigate the relationship for Germany.
} 
literature shows that collective bargaining raises wages and reduces wage inequality (e.g. Blau and Kahn 1996, Card et al. 2003, Fitzenberger and Kohn 2005, Gürtzgen 2006). Some studies also examine the effect of collective bargaining on the entire wage distribution (e.g. Fitzenberger and Kohn 2005, Burda et al. 2008, Fitzenberger et al. 2008). In the analysis, I consider collective bargaining by including dummy variables indicating whether the establishment is covered by an industry-wide or firm-specific wage agreement. ${ }^{17}$ In addition to collective wage contracts, works councils have an impact on wage distributions within establishments (Hübler and Jirjahn 2003). Although works councils’ co-determination rights do not formally include negotiating over wages, they may negotiate about placing workers in higher wage groups. Among other things they can also co-decide on the introduction of new payment schene, overtime work and working conditions. Freeman and Lazear (1995) point out that co-determination confirms the bargaining power of employees. Hübler and Jirjahn (2003) argue that on the one hand works councils strengthen trust and cooperation between the management and the workforce. Thus, the works councils can support the management in implementing new productivity-enhancing work practices. On the other hand, works councils can also prevent the implementation of work practices which are not desired by the workforce. Thus, co-determination may considerably weaken the management's bargaining position. Overall, one can conclude that the presence of works councils may have an impact on both the creation and redistribution of economic rents. Thus, I also control for the presence of a works council.

Further establishment controls in the wage equation are the wage bill per employee, the number of the average agreed working hours, a dummy variable indicating whether the establishment has been found after 1989 and 10 industry dummies.

The descriptive statistics of the establishment characteristics are given in Table A2. The summary statistics indicate that male employees, on average, work in larger, more exportorientated firms than female employees. Further men are rather employed in establishments applying wage agreements and with higher sales per employee than women. There are only small differences between an average man's and an average woman's workplace regarding the state of the technology, the presence of a works council in the establishment and profits of the last year.

\footnotetext{
${ }^{17}$ In Germany, industry-specific unions and employers' associations negotiate industry-wide agreements. Then the agreement is applied to all member firms of the employers' association who signed the contract. A firm can also directly negotiate with a labor union if the firm is not member of an employers' association. Empirical studies (e.g. Stephan and Gerlach 2005, Gürtzgen 2006, Fitzenberger et al. 2008) provide evidence of a positive and significant wage premium of industry-wide and firm-specific wage agreements for western Germany.
} 


\section{Empirical results}

\subsection{Distribution of the gender wage gap}

Before I present and discuss my estimation and decomposition results I address the actual raw gender wage gap. Thus, all following statements refer to wage rates after the imputation (as described in Section 4.1). The usual procedure to measure the male-female wage gap is to consider the differences between the average male wage and its female counterpart. In my sample, the average male daily wage is 105.47 Euro, whereas the average daily wage for women is 83.40 Euro. Therefore, the male-female average wage differential is 22.07 Euro. When I undertake the same calculation but consider log daily wages, the male-female average wage gap turns out to be 0.2347 log points. Thus, in my sample women earn, on average, about 23.5 percent less than men.

Figure 1 shows nonparametric estimates of the density functions of male and female (log) daily wages. ${ }^{18}$ The male wage density is placed rightward with respect to the female wage distribution, indicating a non negligible raw gender wage gap.

Figure 1: Density functions of male and female (log) daily wages

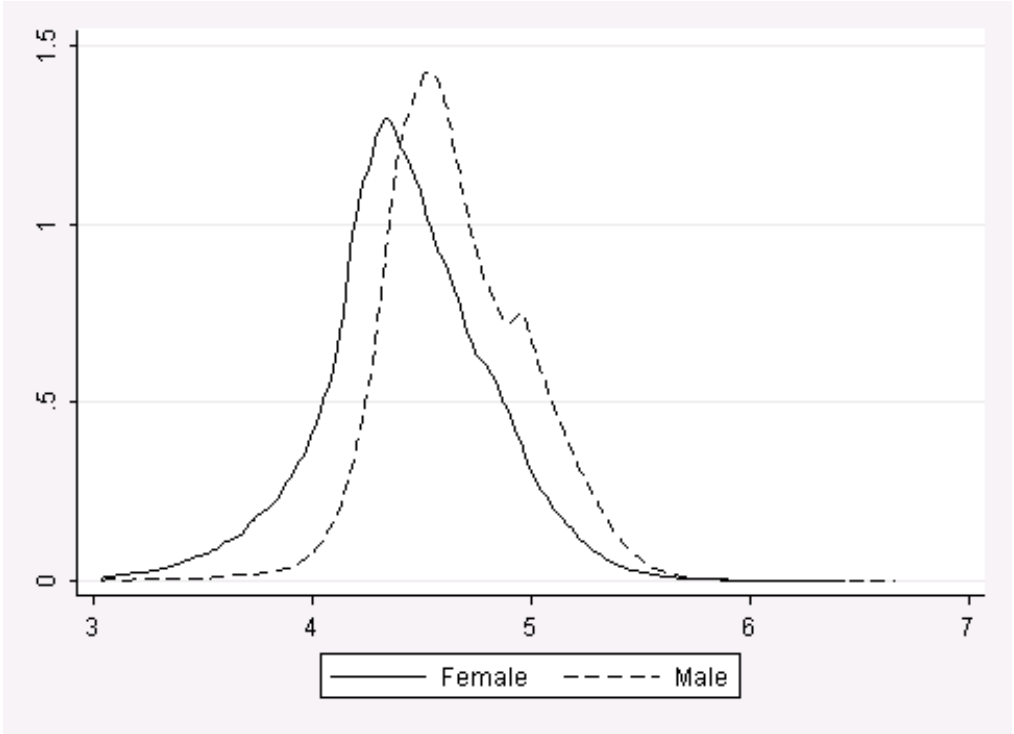

Note: Kernel density wage estimation of man and women use Epanechnikov kernel function. The daily log wage rate after imputation is used.

Source: own calculation; LIAB cross-sectional model 1997-2001.

\footnotetext{
${ }^{18}$ Densities are estimated using an adaptive Epanechnikov kernel. The peak (in particular in the function for male employees) reflects a cluster of wages below the threshold above which wages are top-coded.
} 
Figure 2: Gender wage gap at quantiles

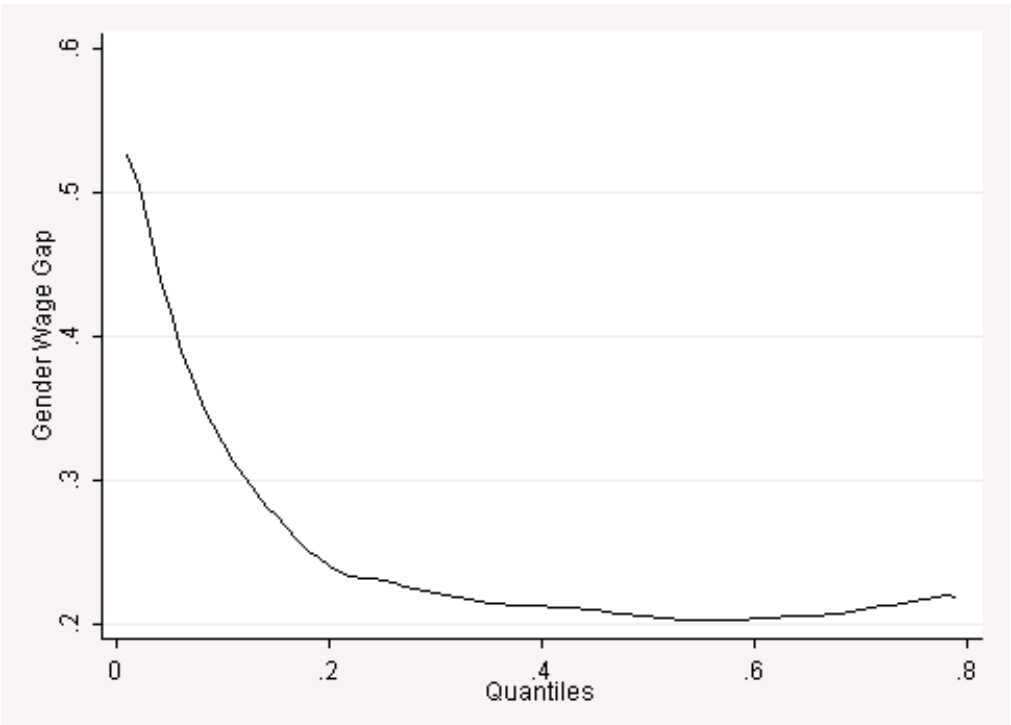

Note: The gender wage gap is the difference between the log wage rate of male and female employees at the quantiles of the wage distribution.

Source: own calculation; LIAB cross-sectional model 1997-2001.

Figure 2 plots the raw gender wage gap as a function at quantiles of the wage distributions. ${ }^{19}$ The gap is distributed unequally across the wage distribution. The wage gap lies above its mean at low wages, drops below the mean around the $30^{\text {th }}$ percentile and keeps on falling until the $60^{\text {th }}$ percentile.

In contrast to other countries like Sweden (Albrecht et al. 2003), Spain (Gardeazabal and Ugidos 2005), Finnland or Denmark (see Arulampalam et al. 2007), the wage gap across the wage distribution has no increasing trend in Germany. Based on other sample definitions and data sets, Fitzenberger and Kunze (2005) and Hübler (2005) also find that the German gender wage gap is large in the lower part of the wage distribution and decreases as the quantiles increase. This falling tendency is not completely confirmed by Arulampalam et al. (2007). They reveal a u-shaped form of the wage gap. Figure 2 resembles the falling tendency of the wage gap with increasing quantiles. Whether it is increasing again in the upper tail of the wage distributions cannot be examined due to top-coding of wages. Still, the gender wage gap is far from being stable across the wage distribution.

\footnotetext{
${ }^{19}$ I present the gap only until the $80^{\text {th }}$ percentile, because the latter percentiles are too unreliable implicated by the imputation.
} 


\subsection{Regression results}

The first step in the empirical analysis of the gender wage differential is to estimate the log wage equations for male and female employees. As discussed in Section 4.2, in addition to individual characteristics, establishment characteristics serve as covariates.

As mentioned in Section 3.2, for the gap decomposition across the wage distribution, it is necessary to estimate the wage by quantile regressions at each percentile of the wage distribution. In sum, this decomposition requires to run 99 quantile regressions for male and 99 quantile regressions for female employees. For comparison, I also present the decomposition of the average pay gap, for example OB decomposition. For this, I estimate separate wage equations by OLS for men and women.

Table A3 and Table A4 in the appendix show the OLS coefficients with their standard errors and the coefficient estimated by quantile regressions for a subset of quantiles of the distributions ${ }^{20}$. All estimated effects in the OLS regressions are significantly different from zero. The variables describing the human capital have the expected effects for both male and female employees: wages increase with the education level, age indicating potential experience and job tenure. The findings also show that, on average, unqualified and qualified blue collar workers as well as individuals in service occupations earn much less than employees in an administrative occupation. That holds for male and female employees. The estimated quantile regression coefficients for the individual characteristics show the same pattern as in the OLS regressions, but vary across the wage distribution. The effect of tertiary education levels, such as a university or a technical university degree, decreases with increasing quantiles of the wage distribution for male employees, while the impact of this covariate increases with increasing quantiles for women. The same holds for the variable age. Without having standard errors, these findings should only be interpreted as some indication.

Turning to the establishment variables, I find that wage rates increase with the number of employees and with the share of highly qualified employees for both men and women. The OLS regressions indicate that the share of female employees affects the wage rate of women and men negatively. This negative impact might reflect a sorting of women into firms with a preferred work environment for which lower compensating wages are paid. This hypothesis as well as alternative explanations are intensely investigated in the next chapter. The quantile

\footnotetext{
${ }^{20}$ The results for the other percentiles are available upon request from the author.
} 
regression results show that the impact of variables describing the workforce decreases with increasing quantiles of the wage distribution for male and female employees.

The OLS findings further indicate that establishments with higher sales per employee, good results in the last year and a state-of-the-art production technology tend to pay higher wage rates both for male and female employees. Apparently, the workforce benefits from the success of the establishment in terms of higher wage rates. The export quota has a positive impact on the wage rate in the OLS regression. This indicates that exporting establishments are more productive and able to pay higher wages rates than establishments operating only on the national market. Whether this result is due to self-selection of more productive establishments in entering the foreign market or due to an increase of the productivity driven by international competition can not be concluded from this kind of analysis (see Schank et al. 2010).

Furthermore, the OLS findings indicate that establishments covered by an industry-wide or firm-specific wage agreement tend to pay higher wage rates than establishments which do not apply such wage agreements. Note that the impact of these institutional variables decreases with increasing quantiles of the wage distribution for both male and female employees. This finding can be explained by the compression of the wage distributions due to collective bargaining and is in line with Burda et al. (2008). Furthermore, the OLS results reveal a strong positive effect of works councils on the wage rate. Note, that the estimated coefficient for this covariate is much higher for women than for men. As the quantile regression estimates show, the impact also increases with increasing quantiles of the wage distribution. The findings regarding the impact of works councils on wages and the wage distribution are in line with Addison et al. (2010) who study this issue for Germany.

\subsection{Decomposition results}

As mentioned in Section 3.2, the estimated quantile regression coefficients and randomly drawn samples of male and female covariates are used to simulate counterfactual wage distributions. The decomposition of the gender wage gap across the wage distributions is implemented, as shown in equation (6). Table 1 presents the gender wage gap and the four decomposition parts at eight deciles. Unfortunately, due to computational constraints at the research data center, I cannot provide standard errors. 
Table 1: MM decomposition at selected quantiles and OB decomposition

\begin{tabular}{cccccc}
\hline \hline Quantiles & $\begin{array}{c}\text { Gender } \\
\text { wage gap }\end{array}$ & \multicolumn{3}{c}{ Wage differential due to difference in ... } \\
\cline { 3 - 6 } & & $\begin{array}{c}\text { individual } \\
\text { characteristics }\end{array}$ & $\begin{array}{c}\text { returns to } \\
\text { individual } \\
\text { characteristics }\end{array}$ & $\begin{array}{c}\text { establishment } \\
\text { characteristics }\end{array}$ & $\begin{array}{c}\text { returns to } \\
\text { establishment } \\
\text { characteristics }\end{array}$ \\
\hline 0.1 & 0.3256 & 0.0207 & 0.0066 & 0.0493 & 0.2255 \\
0.2 & 0.2405 & 0.0089 & -0.0095 & 0.0391 & 0.2153 \\
0.3 & 0.2218 & -0.0024 & -0.0126 & 0.0350 & 0.2107 \\
0.4 & 0.2122 & -0.0131 & -0.0077 & 0.0326 & 0.2044 \\
0.5 & 0.2054 & -0.0250 & 0.0027 & 0.0281 & 0.1996 \\
0.6 & 0.2035 & -0.0330 & 0.0139 & 0.0236 & 0.1955 \\
0.7 & 0.2098 & -0.0297 & 0.0257 & 0.0197 & 0.1875 \\
0.8 & 0.2159 & -0.0114 & 0.0410 & 0.0168 & 0.1643 \\
\hline OB & 0.2347 & -0.0224 & 0.0470 & 0.0509 & 0.1592 \\
\hline \hline
\end{tabular}

Note: The results are based on the log of the imputed daily wage. The gender wage gaps are calculated as the difference between log male wages and log female wages.

Source: own calculation; LIAB cross-sectional model 2002

For comparison, the last row in Table 1 includes the mean gender wage gap and four decomposition parts based on an OB decomposition (see equation (4)). As mentioned before, the mean gender wage gap is 23.5 percent. The largest proportion of the observed raw wage gap is explained by differences in returns to establishment characteristics. Thus, if male and female employees were comparable regarding their individual and establishment characteristics and they had the same returns to their individual characteristics, then nevertheless women would earn 16 percent less on average than men. This could be interpreted as a pay gap within firms and is in line with a result of Hinz and Gartner (2005). By contrast, the contribution of the differences in individual characteristics to the mean pay gap is small and negative. This implies that on average, women would receive lower wages if they had the same endowment of productivity-related individual characteristics as male employees. This result suggests that full-time employed women are well educated.

Furthermore, the OB decomposition shows that the gap attributable to differences in establishment characteristics and the gap referring to differences in the returns to individual characteristics are equally high.

The OB decomposition is limited to decomposing the mean gender wage gap. The MM decomposition based on quantile regression considers the entire wage distribution. The four decomposition parts at each percentile of the wage distributions are also presented in Figure 3. The extreme quantiles are not presented because of unrobust estimates. 
Figure 3: MM decomposition of the gender wage gap

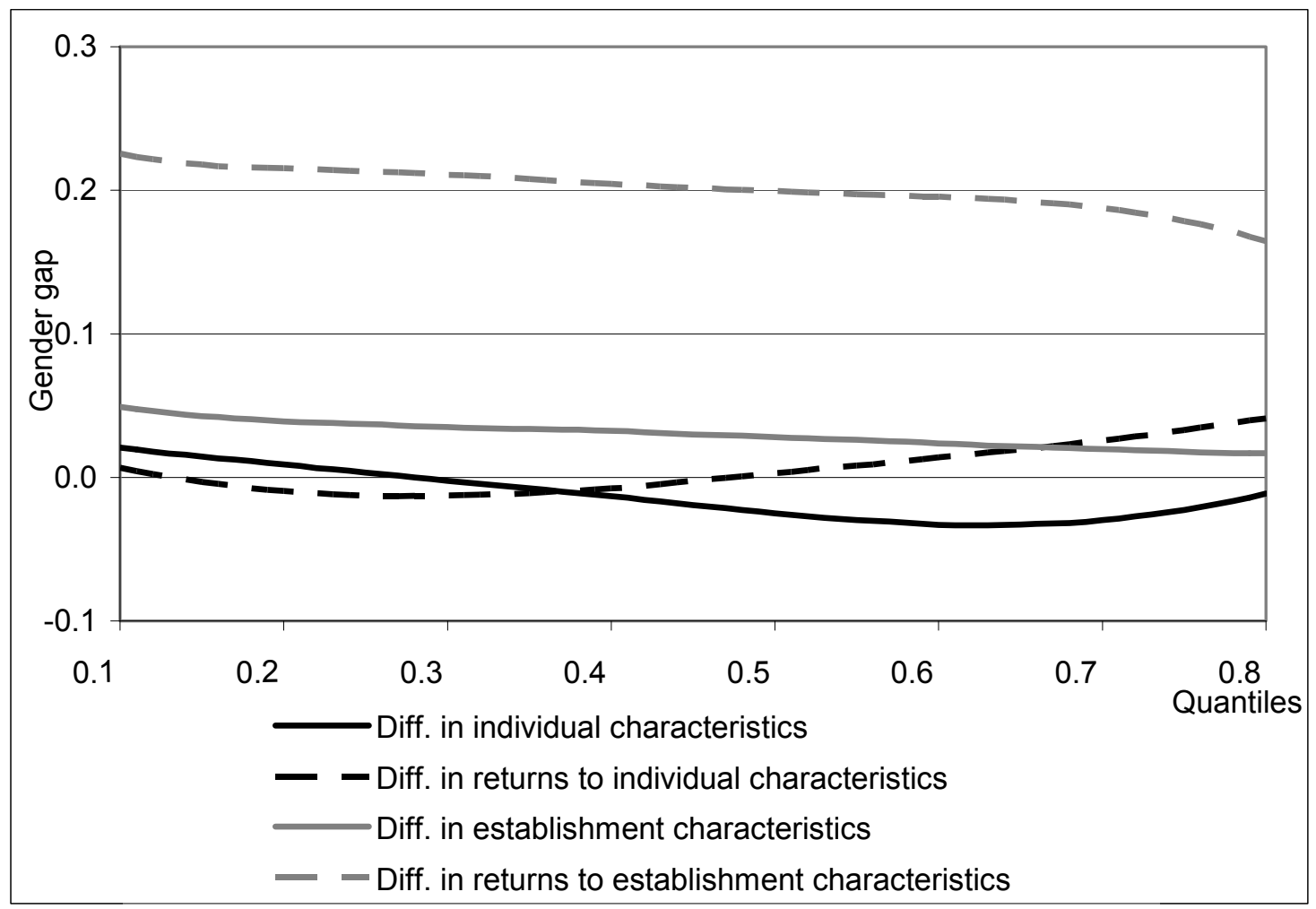

Source: own calculation; LIAB cross-sectional model 2002

The decomposition terms vary across the quantiles of the wage distribution. However, the variation is not as strong as other international studies indicate that only take into account individual characteristics (e.g. Albrecht et al. 2003 for Sweden, De la Rica et al. 2008 for Spain, Arulampalam et al. 2007 among other countries also for Germany). The estimated quantile regression coefficients already provide first hints on these relatively small variations across the quantiles of the wage distribution.

Similar to the OB decomposition, the largest fraction of the gender wage gap is attributable to differences in establishment-specific coefficients across the whole wage distribution. This finding is readily identifiable in Figure 3. This part of the pay gap slightly decreases with increasing quantiles of the wage distributions. Apparently, women benefit less from rents which might be shared between employer and employees than male colleagues. Or in other words, women tend to participate less in the success of the establishment, especially in the lower wage groups. Maybe, they are more diffident in wage negotiations with their superior or they have less bargaining power in comparison to male employees.

Furthermore, Figure 3 shows that there is a male wage premium for the establishment characteristics across the whole distribution. This part also slightly decreases as the quantiles increase. In the lower part of the wage distribution women tend to work in firms which are 
less productive and profitable in comparison to firms where men are typically employed. This also contributes considerably to the gender wage gap. The differences in establishment characteristics are less important for the gap in the upper tail of the wage distribution. It seems that male and female employees in the upper tail of the wage distribution work in similar firms. Unfortunately, I cannot say anything about the statistical significance because the calculation of significance bonds with a bootstrap method is not possible given the computation time.

The fraction of the gender wage gap that is attributable to differences in individual characteristics and the part due to differences in the returns to those characteristics vary around zero along the wage distribution. In the lower part of the wage distribution the fraction due to differences in individual characteristics is positive. Below the $30^{\text {th }}$ percentile, men are endowed with the better paid productivity-related characteristics. By contrast, the reverse holds from above the $30^{\text {th }}$ percentile. This suggests that women in the middle and the upper tail of the wage distribution receive a higher wage rate given their better human capital endowment and their occupations, ceteris paribus.

The decomposition part due to differences in returns to individual characteristics is at first negative and then becomes positive. Between the $15^{\text {th }}$ and the $45^{\text {th }}$ percentile of the wage distribution women get higher returns for their human capital endowment than male employees.

The findings of the OB decomposition of the mean gender wage gap and the MM decomposition of the gap across the whole distribution both suggest the selection of women into less successful and productive firms. In addition, women participate in the success of firms by rent-sharing to a lesser extent than their male colleagues. This is the source of the largest part of the pay gap. The firm and respectively the workplace seem to be very important in explaining wage differentials between male and female employees. This finding is line with results of Drolet (2002), Datta Gupta and Rothstein (2005) as well as Simón and Russell (2005). Gender differences in human capital and occupations as well as differences in returns to these characteristics are less responsible for the wage differential.

\section{Conclusions}

This study investigates the role of individual characteristics and the establishments in determining the gender wage gap across the whole wage distribution in Germany. It thus differs from existing analysis examining the decomposition of the gender wage gap in three respects. First, instead of limiting the explanatory variables to individual characteristics, I 
include a set of detailed establishment characteristics. Second, I extend the traditional OB decomposition to disentangle the effect of human capital characteristics and the effect of establishment characteristics in explaining the gender wage gap. This approach yields new insights into what causes the gender wage gap. Are women less educated or do they work in worse firms compared to men? Third, I implement the decomposition across the entire wage distribution with the Machado Mata method.

The unconditional gender gap is sharply decreasing within the first quartile of the wage distribution and then the decrease decelerates until the $60^{\text {th }}$ percentile, and from then on the gap slightly increases. The gender wage gap is not constant across the wage distribution, but the decomposition terms only vary slightly across the wage distribution. This result suggests that the sources of the wage differential are similar for high- and low-paid employees. One methodological reason for this may be that the top-coding of the data prevents an analysis of the gender wage gap above the $80^{\text {th }}$ percentile. Strong changes in the decomposition of the wage gap might only occur in the upper quantiles though. As a robustness check, a similar analysis with the German Structure of Earnings Survey (GSES), another large German linked employer-employee data set might be helpful. ${ }^{21}$

The present analysis shows that the selection of women into less successful and productive firms explains a sizeable part of the gap. This selection is more pronounced in the lower part of the wage distribution than in the upper tail. In addition, women also benefit from the success of firms by rent-sharing to a lesser extent than their male colleagues. This suggests the largest part of the gap is a wage gap within firms. The establishment seems to be very important in explaining wage differentials between male and female employees. Gender differences in human capital endowment as well as differences in returns to human capital are less responsible for the wage differential. In the middle and upper part of the wage distribution women even have better paid individual characteristics compared to their male colleagues.

These are important findings from a public policy viewpoint. In particular, the findings pose the question why women participate less in the success of firms and what can be done about it. An explanation for married or cohabitating women could be that they have less bargaining power within firms than their male colleagues if they face a limited number of alternative job opportunities due to being tied to the regional labor market of the male breadwinner. The weak bargaining position of women may thus partially reflect the weak bargaining position within their relationship. A separate analysis for single and married/cohabitating women

\footnotetext{
${ }^{21}$ The German Structure of Earnings Survey is a linked employer-employee data set. It is conducted by the Federal Statistical Office. However, the establishment information is not so rich as in the LIAB.
} 
might shed light on the relevance of this argument. If women's weaker bargaining position proves relevant, policies aiming at a reduction of the gender wage gap should strengthen women's bargaining position in the private sphere by for example improving the public child care infrastructure or abolishing the employment disincentive inherent in the German tax system. In addition, women - irrespective of their marital status - might be too hesitant compared to their male colleagues to demand the merits of their work as a share of the firm's rents. If this was the case, women should be encouraged to seek wage negotiations with the aim of enjoying greater financial rewards. 


\section{Appendix}

Table A1: Summary statistics of individual characteristics for male and female employees

\begin{tabular}{llllll}
\hline \hline & \multicolumn{2}{c}{ Males } & & \multicolumn{2}{c}{ Females } \\
\cline { 2 - 3 } \cline { 5 - 6 } Variables & Mean & Std. dev. & & Mean & Std. dev. \\
\hline Log wage (imputated) & 4.6584 & 0.3225 & & 4.4237 & 0.3776 \\
Log wage (censored) & 4.6205 & 0.2610 & & 4.4089 & 0.3492 \\
Age & 40.7127 & 7.8045 & & 39.5960 & 8.3721 \\
Job tenure (in month) & 138.0195 & 98.6705 & & 119.0050 & 93.6713 \\
Low education without vocational & 0.1161 & 0.3204 & & 0.2033 & 0.4024 \\
training degree & & & & \\
Vocational training degree & 0.7030 & 0.4569 & & 0.6229 & 0.4847 \\
High school without vocational training & 0.0065 & 0.0802 & & 0.0122 & 0.1096 \\
degree & & & & \\
High school with vocational training & 0.0319 & 0.1758 & & 0.0704 & 0.2559 \\
degree & & & & 0.0340 & 0.1812 \\
Technical university degree & 0.0728 & 0.2598 & & 0.0572 & 0.2323 \\
University degree & 0.0697 & 0.2546 & & 0.059 \\
Simple blue-collar occupation & 0.2549 & 0.4358 & & 0.2211 & 0.4150 \\
Qualified blue-collar occupation & 0.2346 & 0.4237 & & 0.0445 & 0.2062 \\
Engineer & 0.1965 & 0.3973 & & 0.0812 & 0.2732 \\
Service occupation & 0.1177 & 0.3222 & & 0.0886 & 0.2841 \\
Clerical and administrative occupation & 0.1480 & 0.3551 & & 0.4771 & 0.4995 \\
Profession, manager and others & 0.0483 & 0.2145 & & 0.0876 & 0.2827 \\
\hline Number of employees & & 384,908 & & 98,368 \\
\hline \hline
\end{tabular}

Source: own calculation; LIAB cross-sectional model 2002 
Table A2: Summary statistics of establishment characteristics for male and female employess

\begin{tabular}{|c|c|c|c|c|}
\hline \multirow[b]{2}{*}{ Variables } & \multicolumn{2}{|c|}{ Males } & \multicolumn{2}{|c|}{ Females } \\
\hline & Mean & Std. dev. & Mean & Std. dev. \\
\hline Employment size $\left(1 / 10^{3}\right)$ & 2.3976 & 3.9996 & 1.7425 & 3.0503 \\
\hline Proportion of female employees & 0.2089 & 0.1604 & 0.3976 & 0.2354 \\
\hline $\begin{array}{l}\text { Proportion of highly qualified } \\
\text { employees }\end{array}$ & 0.6855 & 0.2527 & 0.6500 & 0.2625 \\
\hline Business start-up after 1989 & 0.1484 & 0.3555 & 0.1473 & 0.3544 \\
\hline Export quota (sales) & 0.3077 & 0.2956 & 0.2512 & 0.2821 \\
\hline Wage bill per employee $\left(1 / 10^{3}\right)$ & 5.8003 & 2.0433 & 5.3250 & 2.3203 \\
\hline Sales per employee $\left(1 / 10^{5}\right)$ & 5.0887 & 13.6998 & 5.3275 & 19.7887 \\
\hline Good results last year & 0.3595 & 0.4799 & 0.3527 & 0.4778 \\
\hline Bad results last year & 0.2826 & 0.4503 & 0.2895 & 0.4535 \\
\hline Average results last year & 0.3579 & 0.4794 & 0.3578 & 0.4793 \\
\hline State of the technology & 2.9817 & 0.7145 & 2.9974 & 0.7160 \\
\hline Industry-wide wage agreement & 0.7778 & 0.4157 & 0.7286 & 0.4447 \\
\hline Firm-specific wage agreement & 0.1128 & 0.3163 & 0.1048 & 0.3063 \\
\hline No wage agreement & 0.1094 & 0.3122 & 0.1667 & 0.3727 \\
\hline Works council & 0.9156 & 0.2780 & 0.8733 & 0.3326 \\
\hline Average weekly working hours & 36.7957 & 1.8723 & 37.2115 & 1.7615 \\
\hline $\begin{array}{l}\text { Agriculture and forestry, electricity, } \\
\text { gas and water supply, mining }\end{array}$ & 0.0384 & 0.1922 & 0.0251 & 0.1564 \\
\hline Manufacturing I & 0.2190 & 0.4136 & 0.1785 & 0.3830 \\
\hline Manufacturing II & 0.4981 & 0.5000 & 0.4113 & 0.4921 \\
\hline Construction & 0.0344 & 0.1822 & 0.0148 & 0.1206 \\
\hline Wholesale and retail trade & 0.0541 & 0.2262 & 0.1341 & 0.3407 \\
\hline Transport and communication & 0.0687 & 0.2530 & 0.0462 & 0.2100 \\
\hline Financial intermediation & 0.0013 & 0.0360 & 0.0010 & 0.0320 \\
\hline $\begin{array}{l}\text { Real estate, renting and business } \\
\text { activities }\end{array}$ & 0.0527 & 0.2235 & 0.0695 & 0.2543 \\
\hline Education & 0.0028 & 0.0524 & 0.0056 & 0.0746 \\
\hline Other service activities & 0.0306 & 0.1721 & 0.1138 & 0.3176 \\
\hline Berlin-West & 0.0432 & 0.2034 & 0.0583 & 0.2343 \\
\hline Schleswig Holstein & 0.0503 & 0.2185 & 0.0602 & 0.2379 \\
\hline Hamburg & 0.0588 & 0.2352 & 0.0522 & 0.2225 \\
\hline Lower Saxony & 0.0841 & 0.2775 & 0.0745 & 0.2625 \\
\hline Bremen & 0.0298 & 0.1700 & 0.0352 & 0.1843 \\
\hline North Rhine-Westphalia & 0.1982 & 0.3986 & 0.1681 & 0.3739 \\
\hline Hesse & 0.1332 & 0.3398 & 0.1330 & 0.3395 \\
\hline Rhineland-Palatinate & 0.0472 & 0.2120 & 0.0559 & 0.2298 \\
\hline Baden-Wuerttemberg & 0.1290 & 0.3352 & 0.1572 & 0.3640 \\
\hline Bavaria & 0.1668 & 0.3728 & 0.1664 & 0.3724 \\
\hline Saarland & 0.0595 & 0.2365 & 0.0391 & 0.1937 \\
\hline Number of employees & \multicolumn{2}{|c|}{384,908} & \multicolumn{2}{|c|}{98,368} \\
\hline
\end{tabular}

Source: own calculation; LIAB cross-sectional model 2002 
Table A3: Estimates of OLS and Quantile wage regressions for male employees

\begin{tabular}{|c|c|c|c|c|c|c|}
\hline \multirow[b]{3}{*}{ Variables } & \multicolumn{2}{|c|}{ OLS regression } & \multicolumn{4}{|c|}{ Quantile regression } \\
\hline & & & $\theta=0.10$ & $\theta=0.25$ & $\theta=0.50$ & $\theta=0.75$ \\
\hline & \multicolumn{2}{|c|}{ Coeff. Std. err. } & Coeff. & Coeff. & Coeff. & Coeff. \\
\hline Age & $0.0374^{\star * *}$ & 0.0004 & 0.0341 & 0.0335 & 0.0305 & 0.0299 \\
\hline Age squared $\left(1 / 10^{2}\right)$ & $-0.0398^{* * *}$ & 0.0005 & -0.0376 & -0.0363 & -0.0325 & -0.0313 \\
\hline $\begin{array}{l}\text { Low education without vocational } \\
\text { training degree }\end{array}$ & $-0.0936^{* * *}$ & 0.0011 & -0.0844 & -0.0798 & -0.0775 & -0.0845 \\
\hline $\begin{array}{l}\text { Vocational training degree } \\
\text { (reference) }\end{array}$ & - & & - & - & & \\
\hline $\begin{array}{l}\text { High school without vocational } \\
\text { training degree }\end{array}$ & $0.0442^{* * *}$ & 0.0041 & -0.0138 & 0.0323 & 0.0631 & 0.0603 \\
\hline $\begin{array}{l}\text { High school with vocational } \\
\text { training degree }\end{array}$ & $0.0858^{* * *}$ & 0.0019 & 0.0563 & 0.0688 & 0.0872 & 0.0916 \\
\hline ersity degree & $0.2146^{* * *}$ & 0.0014 & 0.2432 & 0.2218 & 0.2054 & 0.1978 \\
\hline University degree & $0.2937^{* * *}$ & 0.0015 & 0.3164 & 0.3046 & 0.2838 & 0.2692 \\
\hline Simple blue-collar occupation & $-0.2594^{* * *}$ & 0.0012 & -0.1507 & -0.2034 & -0.2695 & -0.3272 \\
\hline Qualified b & $-0.2087^{* * *}$ & 0.0012 & -0.1137 & -0.1610 & -0.2228 & -0.2735 \\
\hline Engineer & $0.0259^{* * *}$ & 0.0012 & 0.0599 & 0.0448 & 0.0230 & 0.0072 \\
\hline Service occupation & $-0.2566^{\star * *}$ & 0.0014 & -0.1846 & -0.2195 & -0.2739 & -0.3099 \\
\hline $\begin{array}{l}\text { Clerical and ac } \\
\text { occupation (re }\end{array}$ & - & & 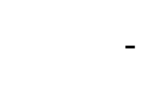 & & & \\
\hline Profession, manager and others & $0.0540^{* * *}$ & 0.0018 & 0.0536 & 0.0707 & 0.0696 & 0.0599 \\
\hline Job tenure (in month) $\left(1 / 10^{2}\right)$ & $0.0334^{\star * *}$ & 0.0004 & 0.0417 & 0.0359 & 0.0315 & 0.0299 \\
\hline Employment size $\left(1 / 10^{3}\right)$ & $0.0179^{* * *}$ & 0.0003 & 0.0224 & 0.0212 & 0.0200 & 0.0151 \\
\hline Employment size squared $\left(1 / 10^{6}\right)$ & $-0.0007^{* * *}$ & & -0.0009 & -0.0008 & -0.0008 & -0.0005 \\
\hline Proportion of female en & $-0.0970^{* * *}$ & & -0.1362 & -0.1289 & -0.1035 & -0.0719 \\
\hline $\begin{array}{l}\text { Proportion of highly c } \\
\text { employees }\end{array}$ & $0.0803^{* * *}$ & 0.0015 & 0.0767 & 0.0569 & 0.0589 & 0.0648 \\
\hline tart-up after 1989 & & & & & & 0.0433 \\
\hline Export quota (sales) & $0.0099^{* * *}$ & 0.0015 & 0.0107 & 0.0090 & 0.0019 & 0.0012 \\
\hline Wage bill per employee $\left(1 / 10^{3}\right)$ & $0.0230^{\star * *}$ & 0.0002 & 0.0231 & 0.0271 & 0.0289 & 0.0279 \\
\hline Sales per employee $\left(1 / 10^{5}\right)$ & $0.0005^{\star * *}$ & & 0.0006 & 0.0007 & 0.0007 & 0.0007 \\
\hline Good results last year & & & 0.0140 & 0.0147 & 0.0168 & 0.0156 \\
\hline Bad results last year & $-0.0072^{* * *}$ & 0.0009 & -0.0110 & -0.0068 & -0.0038 & -0.0055 \\
\hline $\begin{array}{l}\text { Average results last year } \\
\text { (reference) }\end{array}$ & 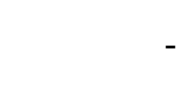 & & & & & \\
\hline the technology & & & 0.0122 & & & 0.0127 \\
\hline Industry-wide wage agreement & & 0.0013 & 0.0634 & 0.0472 & 0.0368 & 0.0207 \\
\hline Firm-specific wage agreement & $0.0214^{* * *}$ & 0.0016 & 0.0240 & 0.0231 & 0.0224 & 0.0130 \\
\hline No wage agreement (reference) & - & - & - & - & - & \\
\hline Works council & $0.0870^{* * *}$ & 0.0014 & 0.1177 & 0.0940 & 0.0762 & 0.0619 \\
\hline Average weekly working hours & $-0.0097^{* * *}$ & 0.0002 & -0.0113 & -0.0103 & -0.0090 & -0.0084 \\
\hline Constant & $3.8928^{* * *}$ & 0.0125 & 3.6841 & 3.8116 & 4.0144 & 4.1908 \\
\hline $\mathrm{R}^{2}$ & & & & & & \\
\hline Number of observations & 384,9 & & & & & \\
\hline
\end{tabular}

Note: The dependent variable is the log of the imputed daily wage. Controls for regions and industries are also included in estimations. Significance levels: *: 10 percent ${ }^{* *}: 5$ percent ${ }^{* * *}: 1$ percent, Quantile regressions are without standard errors.

Source: own calculation; LIAB cross-sectional model 2002 
Table A 4: Estimates OLS and Quantile wage regressions for female employees

\begin{tabular}{|c|c|c|c|c|c|c|}
\hline \multirow[b]{3}{*}{ Variables } & \multicolumn{2}{|c|}{ OLS regression } & \multicolumn{4}{|c|}{ Quantile regression } \\
\hline & & & $\theta=0.10$ & $\theta=0.25$ & $\theta=0.50$ & $\theta=0.75$ \\
\hline & Coeff. & Std. err. & Coeff. & Coeff. & Coeff. & Coeff. \\
\hline Age & $0.0241^{* * *}$ & 0.0010 & -0.0014 & 0.0194 & 0.0305 & 0.0351 \\
\hline Age squared $\left(1 / 10^{2}\right)$ & $-0.0263^{\star * *}$ & 0.0013 & 0.0020 & -0.0227 & -0.0350 & -0.0395 \\
\hline $\begin{array}{l}\text { Low education without vocational } \\
\text { training degree }\end{array}$ & $-0.0843^{* * *}$ & 0.0025 & -0.0602 & -0.0639 & -0.0715 & -0.0816 \\
\hline $\begin{array}{l}\text { Vocational training degree } \\
\text { (reference) }\end{array}$ & - & & 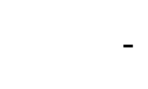 & & & \\
\hline $\begin{array}{l}\text { High school without vocational } \\
\text { training degree }\end{array}$ & $0.0712^{* * *}$ & 0.0078 & -0.0220 & 0.0249 & 0.0780 & 0.1225 \\
\hline $\begin{array}{l}\text { High school } \\
\text { training deg }\end{array}$ & $0.1142^{* * *}$ & 0.0035 & 0.0792 & 0.0834 & 0.0968 & 0.1245 \\
\hline Technical uni & $0.2569^{* * *}$ & 0.0049 & 0.2160 & 0.2255 & 0.2519 & 0.2697 \\
\hline University degree & $0.3563^{* * *}$ & 0.0040 & 0.3008 & 0.3204 & 0.3565 & 0.3890 \\
\hline Simple blue-collar occupation & $-0.1913^{* * *}$ & 0.0028 & -0.0675 & -0.1395 & -0.1963 & -0.2478 \\
\hline Qualified blue-collar occupation & $-0.1844^{* * *}$ & 0.0044 & -0.1033 & -0.1533 & -0.1975 & -0.2212 \\
\hline Engineer & $0.0154^{* * *}$ & 0.0034 & 0.0554 & 0.0330 & 0.0101 & -0.0115 \\
\hline Service occupation & $-0.1560^{\star \star *}$ & 0.0034 & -0.1357 & -0.1554 & -0.1487 & -0.1443 \\
\hline $\begin{array}{l}\text { Clerical and administrative } \\
\text { occupation (reference) }\end{array}$ & - & & & & & \\
\hline Profession, manager and others & $0.0860^{* * *}$ & 0.0037 & 0.1170 & 0.1113 & 0.0960 & 0.0765 \\
\hline Job tenure (in month) $\left(1 / 10^{2}\right)$ & $0.0428^{* * *}$ & 0.0011 & 0.0524 & 0.0457 & 0.0401 & 0.0343 \\
\hline Employment size $\left(1 / 10^{3}\right)$ & $0.0270^{\star * *}$ & 0.0009 & 0.0381 & 0.0300 & 0.0247 & 0.0188 \\
\hline Employment size squared $\left(1 / 10^{6}\right)$ & $-0.0010^{* * *}$ & 0.0001 & -0.0015 & -0.0012 & -0.0010 & -0.0006 \\
\hline Proportion of female employees & $-0.0762^{* * *}$ & 0.0049 & -0.0939 & -0.0862 & -0.0902 & -0.0794 \\
\hline $\begin{array}{l}\text { Proportion of highly qu } \\
\text { employees }\end{array}$ & $0.1406^{* * *}$ & 0.0039 & 0.1896 & 0.1094 & 0.0825 & 0.0883 \\
\hline tart-up after 1989 & $0.0431^{* * *}$ & 0.0026 & 0.0181 & 0.0271 & & 0.0488 \\
\hline Export quota (sales) & $0.0476^{* * *}$ & 0.0042 & 0.0222 & 0.0422 & 0.0480 & 0.0364 \\
\hline Wage bill per employee $\left(1 / 10^{3}\right)$ & $0.0304^{* * *}$ & 0.0004 & 0.0249 & 0.0355 & 0.0395 & 0.0421 \\
\hline Sales per employee $\left(1 / 10^{5}\right)$ & $0.0001^{* * *}$ & 0.0000 & 0.0001 & 0.0000 & 0.0000 & 0.0002 \\
\hline Good results & $0.0222^{* * *}$ & 0.0021 & 0.0215 & 0.0276 & 0.0257 & 0.0255 \\
\hline Bad res & $0.0073^{\star * *}$ & 0.0022 & -0.0054 & 0.0095 & 0.0116 & 0.0140 \\
\hline $\begin{array}{l}\text { Average results last year } \\
\text { (reference) }\end{array}$ & - & & & & & \\
\hline technology & $0.0130^{* * *}$ & 0.0013 & 0.0123 & 0.0103 & 0.0086 & 0.0066 \\
\hline Industry-wide wage agreement & $0.0470^{\star \star \star}$ & 0.0028 & 0.0923 & 0.0572 & 0.0483 & 0.0357 \\
\hline Firm-specific wage agreement & $0.0270^{* * *}$ & 0.0038 & 0.0742 & 0.0377 & 0.0255 & 0.0160 \\
\hline No wage agreement (reference) & - & - & - & - & - & \\
\hline Works council & $0.1555^{\star * *}$ & 0.0031 & 0.2766 & 0.1934 & 0.1315 & 0.1054 \\
\hline Average weekly working hours & $-0.0193^{* * *}$ & 0.0007 & -0.0257 & -0.0205 & -0.0206 & -0.0172 \\
\hline Constant & $4.1050^{* * *}$ & 0.0322 & 4.4006 & 4.0757 & 4.0733 & 4.0419 \\
\hline & & & & & & \\
\hline
\end{tabular}

Note: The dependent variable is the log of the imputed daily wage. Controls for regions and industries are also included in estimations. Significance levels: *: 10 percent $* *: 5$ percent $* * *: 1$ percent, Quantile regressions are without standard errors.

Source: own calculation; LIAB cross-sectional model 2002 


\section{References}

Abowd, J. M. and F. Kramarz (1999): “The Analysis of Labor Markets Using Matched Employer-Employee Data”, in: O. Ashenfelter and D. Card (eds.): Handbook of Labor Economics, Vol. 3(3), chapt. 40, 2629-2733, Elsevier: Amsterdam.

Abowd, J. M. and T. Lemieux (1993): “The Effects of Product Market Competition on Collective Bargaining Agreements: The Case of Foreign Competition in Canada”, Quarterly Journal of Economics, 108(4), 983-1014.

Addison, J. T., Teixeira, P. and T. Zwick (2010): “ German Works Councils and the Anatomy of Wages, Industrial and Labor Relations Review, 63 (1), 250-274.

Albrecht, J., A. Björklund and S. Vroman (2003): “Is There a Glass Ceiling in Sweden?" Journal of Labor Economics, 21(1), 145-177.

Albrecht, J., A. van Vuuren and S. Vroman (2009): "Decomposing the Gender Wage Gap in the Netherlands with Sample Selection Adjustments”, Labour Economics, 16(4), 383396.

Altonji, J. G. and R. M. Blank (1999): "Race and Gender in the Labor Market”, in O. Ashenfelter and D. Card (eds.), Handbook of Labor Economics, Vol. 3(3), chap. 48, 3143-3259, Elsevier: Amsterdam.

Arulampalam, W., A. L. Booth and M. L. Bryan (2007): "Is There a Glass Ceiling over Europe? Exploring the Gender Wage Gap Across the Wages Distribution”, Industrial and Labor Relations Review, 60(2), 161-186.

Bayard, K., Hellerstein, J., Neumark, D. and K. Troske (2003): "New Evidence on Sex Segregation and Sex Differences in Wages from Matched Employee-Employer Data," Journal of Labor Economics, 21(4), 887-922.

Beblo, M., D. Beninger, A. Heinze and F. Laisney (2003): "Measuring Selectivity-Corrected Gender Wage Gaps in the EU”, ZEW Discussion Paper 03-74, Centre for European Economic Research (ZEW), Mannheim.

Bender, S., Haas, A. and C. Klose (2000): "IAB Employment Subsample 1975-1995. Opportunities for Analysis Provided by the Anonymised Subsample”, IZA Discussion Paper 117, Institute for the Study of Labor (IZA), Bonn.

Bernard, A. B. and J. B. Jensen (1999): "Exceptional Exporter Performance: Cause, Effect or Both?”, Journal of International Economics, 47(1), 1-25.

Bernard, A. B. and J. Wagner (1997): “Exports and Success in German Manufacturing”, Review of World Economics, 133(1), 134-157.

Blanchflower, D. G., A. J. Oswals and P. Saney (1996): "Wages, Profits, and Rent-Sharing”, Quarterly Journal of Economics, 111(1), 227-251.

Blau, F. D. and L. M. Kahn (1996): "Wage Structure and Gender Earnings Differentials: An International Comparison”, Economica, 63(250), S29-S62.

Blau, F. D. and L. M. Kahn (2003): "Understanding International Differences in the Gender Pay Gap”, Journal of Labor Economics, 21(1), 106-144.

Blinder, A. S. (1973): “Wage Discrimination: Reduced Form and Structural Estimates”, Journal of Human Resources, 8(4), 436-455.

Bonjour, D. and M. Gerfin (2001): “The Unequal Distribution of Unequal Pay - An Empirical Analysis of the Gender Wage Gap in Switzerland”, Empirical Economics, 26(2), 407427. 
Buchinsky, M. (1994): "Changes in the U.S. Wage Structure 1963-1987: Application of Quantile Regressions”, Econometrica, 62(2) 405-458.

Buchinsky, M. (1998): "Recent Advances in Quantile Regression Models: A Practical Guideline for Empirical Research”, Journal of Human Resources, 33(1), 88-126.

Burda, M. C, B. Fitzenberger, A. Lembke and T. Vogel (2008): "Unionization, Stochastic Dominance, and Compression of the Wage Distribution: Evidence from Germany", SFB 649 Discussion Paper 2008-041, Humboldt University Berlin.

Card, D. (1999): “The Causal Effect of Education on Earnings”, in: O. Ashenfelter and D. Card (eds.): Handbook of Labor Economics, Vol. 3(1), chapt. 30, 1801-1859, Elsevier: Amsterdam.

Card, D., T. Lemieux and W. C. Riddell (2003): "Unions and the Wage Structure”, in: J. T. Addison and C. Schnabel (eds.), The International Handbook of Trade Unions, chap. 8, 246-292, Edward Elgar: Cheltenham UK.

Cardoso, A. R. (2000): "Wage Differentials Across Firms: An Application of Multilevel Modelling”, Journal of Applied Econometrics, 15(4), 343-354.

Carrington, W. J. and K. R. Troske (1998): “Sex Segregation in U.S. Manufacturing”, Industrial and Labor Relations Review, 51(3), 445-464.

Datta Gupta, N. and D. S. Rothstein (2005): “The Impact of Worker and Establishment-Level Characteristics on Male-Female Wage Differentials: Evidence from Danish Matched Employee-Employer Data”, LABOUR: Review of Labour Economics \& Industrial Relations, 19(1), 1-34.

De la Rica, S., J. J. Dolado and V. Llorens (2008): “Ceiling or Floors: Gender Wage Gaps by Education in Spain”, Journal of Population Economics, 21(3), 751-776.

Dolado, J. J., F. Felgueroso and J. F. Jimeno (2004): “Where Do Women Work?: Analysis Patterns of Occupational Segregation by Gender", Annales d'Economie et de Statistique (Special Issue on Discrimination and Unequal Outcomes), 71/72(3), 293315.

Donald, S. G., D. A. Green and H. J. Paarsch (2000): “Differences in Wage Distribution Between Canada and the United States: An Application of a Flexible Estimator of Distributions Functions in the Presence of Covariates”, Review of Economic Studies, 67(4), 609-633.

Drolet, M. (2002): “Can the Workplace Explain Canadian Gender Pay Differentials?”, Canadian Public Policy, 28(1), S41-S63.

Fitzenberger, B. (1997a): “A Guide to Censored Quantile Regressions”, in: G. S Maddala and C. R. Rao (eds.), Handbook of Statistics, Vol. 15: Robust Inference, 405-437, Elsevier: Amsterdam.

Fitzenberger, B. (1997b): “Computational Aspects of Censored Quantile Regression”, in Dodge, Y. (eds.), L1 - Statistical Procedures and Related Topics, Vol. 31 of IMS Lecture Notes - Monograph Series, 171-185, Institute of Mathematical Statistics: Hayward, CA.

Fitzenberger, B., R. Koenker and J. A. F. Machado (2001): "Special Issue on Economic Applications of Quantile Regression”, Empirical Economics, 26 (1), 1-324.

Fitzenberger, B. and K. Kohn (2005): "Gleicher Lohn für gleiche Arbeit? Zum Zusammenhang zwischen Gewerkschaftsmitgliedschaft und Lohnstruktur in Westdeutschland 1985-1997“, Zeitschrift für Arbeitsmarktforschung, 38(2/3), 125146. 
Fitzenberger, B., K. Kohn and A. C. Lembcke (2008): "Union Density and Varieties of Coverage: The Anatomy of Union Wage Effects in Germany", ZEW Discussion Paper 08-012, Centre for European Economic Research (ZEW), Mannheim.

Fitzenberger, B. and A. Kunze (2005): "Vocational Training and Gender: Wages and Occupational Mobility among Young Workers”, Oxford Review of Economic Policy, 21(3), 392-415.

Fortin, N. M. and T. Lemieux (1998): "Rank Regressions, Wage Distributions and the Gender Gap”, Journal of Human Resources, 33(3), 610-643.

Freeman, R. B. and E. P. Lazear (1995): “An Economic Analysis of Works Councils”, in: J. Rogers and W. Streeck (Eds.), Works Councils - Consulting, Representation and Cooperation in Industrial Relations, 27-50, University of Chicago Press: Chicago.

García, J., P. J. Hernández and A. López-Nicolás (2001): "How Wide is the Gap? An Investigation of Gender Wage Differences Using Quantile Regression”, Empirical Economics, 26(1), 149-167.

Gardeazabal, J. and A. Ugidos (2005): “Gender Wage Discrimination at Quantiles”, Journal of Population Economics, 18(1), 165-179.

Gartner, H. (2005): "The Imputation of Wages Above the Contribution Limit with the German IAB Employment Sample”, FDZ Methodenreport 2/2005, Institute for Employment Research (IAB), Nuremberg.

Groshen, E. L. (1991a): “The Structure of the Female/Male Wage Differential: Is It Who You Are, What You Do, or Where You Work?”, Journal of Human Resources, 26(3), 457472.

Groshen, E. L. (1991b): "Sources of Intra-Industry Wage Dispersion: How Much Do Employers Matter?”, Quarterly Journal of Economics, 106(3), 869-884.

Gürtzgen, N. (2006): "The Effect of Firm- and Industry-Level Contracts on Wages Evidence from Longitudinal Linked Employer-Employee Data”, ZEW Discussion Paper 06-082, Centre for European Economic Research (ZEW), Mannheim.

Hinz, T. and H. Gartner (2005): "Geschlechtsspezifische Lohnunterschiede in Branchen, Berufen und Betrieben“, Zeitschrift für Soziologie, 34(1), 22-39.

Hübler, O. (2005): “Is There a Varying Unexplained Gender Wage Gap in Germany?”, Applied Economics Quarterly, 51, 29-48.

Hübler, O. and U. Jirjahn (2003): "Works Councils and Collective Bargaining in Germany: The Impact on Productivity and Wages”, Scottish Journal of Political Economy, 50(4), 471-491.

Juhn, C., Murphy, K. M. and B. Pierce (1993): "Wage Inequality and the Rise in Returns to Skill”, Journal of Political Economy, 101(3), 410-442.

Kerr, C. (1994): “The Social Economics Revisionists: The 'Real World' of Labor Markets and Institutions”, in: C. Kerr, C. and P. D. Staudohar (eds.), Labor Economics and Industrial Relations: Markets and Institutions, 66 - 108, Harvard University Press: Cambridge.

Koenker, R. and G. Bassett (1978): "Regression Quantiles”, Econometrica, 46(1), 33-50.

Koenker, R. and K. F. Hallock (2001): “Quantile Regression”, Journal of Economic Perspectives, 15(4), 143-156.

Koenker, R. and B. J. Park (1996): “An Interior Point Algorithm for Nonlinear Quantile Regression”, Journal of Econometrics, 71(1), 265-283. 
Kohn, K. (2006): "Rising Wage Dispersion, After All! The German Wage Structure at the Turn of the Century”, IZA Discussion Paper 2098, Institute for the Study of Labor (IZA), Bonn.

Kölling, A. (2000): “The IAB Establishment Panel”, Schmollers Jahrbuch, 120(2), 291-300.

Kremer, M. (1993): “The O-Ring Theory of Economic Development”, Quarterly Journal of Economics, 108(3), 551-575.

Machado, J. A. F and J. Mata (2005): "Counterfactual Decomposition of Changes in Wage Distribution Using Quantile Regression”, Journal of Applied Econometrics, 20(4) 445465.

Melitz, M. J., (2003): “The Impact of Trade on Intra-Industry Reallocations and Aggregate Industry Productivity”, Econometrica, 71: 1695-1725.

Melly, B. (2005): "Public-Private Sector Wage Differentials in Germany: Evidence from Quantile Regression”, Empirical Economics, 30(2), 505-520.

Mincer, J. (1974): “Schooling, Experience, and Earnings”, Columbia University Press: New York.

OECD (2002): “Women at Work: Who Are They and How Are They Faring?”, in: OECD (eds.), Employment Outlook 2002, 61-125, Paris.

Oaxaca, R. L. (1973): "Male-Female Wage Differentials in Urban Labor Markets", International Economic Review, 14(3), 693-709.

Oaxaca, R. L. and M. R. Ransom (1994): “On Discrimination and the Decomposition of Wage Differentials”, Journal of Econometrics, 61(1), 5-21.

Oi, W. Y. and T. L. Idson (1999): "Firm Size and Wages", in: O. C. Ashenfelter and D. Card (eds.), Handbook of Labor Economics, Vol. 3(2), chapt. 23, 2165-2214. Elsevier: Amsterdam.

Powell, J. L. (1984): "Least Absolute Deviations Estimation for the Censored Regression Model”, Journal of Econometrics, 25(3), 303-325.

Powell, J. L. (1986): “Censored Regression Quantiles”, Journal of Econometrics, 32(1), 143155.

Reilly, K. T. and T. S. Wirjanto (1999): "Does More Mean Less? The Male/Female Wage Gap and the Proportion of Females at the Establishment Level”, Canadian Journal of Economics, 32(4), 906-929.

Schank, T., C. Schnabel and J. Wagner (2010): "Higher Wages in Exporting Firms: SelfSelection, Export Effect, or Both? First Evidence from German Linked EmployerEmployee Data”, Review of World Economics, 146 (2), 303-322

Schmidt, C. M. and K. F. Zimmermann (1991): "Work Characteristics, Firm Size, and Wages”, Review of Economics \& Statistics, 73(4), 705 - 710.

Silber, J. and M. Weber (1999): "Labour Market Discrimination: Are There Significant Differences Between the Various Decomposition Procedure?”, Applied Economics, 31(3), 359-365.

Simón, H. and H. Russell (2005): "Firms and the Gender Pay Gap: A Cross-National Comparison”, Pay Inequalities and Economic Performance Working Paper 15, London School of Economics (LSE), London.

Sorensen, E. (1990): “The Crowding Hypothesis and Comparable Worth Issue”, Journal of Human Resources, Vol. 25(1), 55-89.

Stephan, G. and K. Gerlach (2005): "Wage Settlements and Wage Setting: Results From a Multi-Level Model”, Applied Economics, 37(20), 2297-2306. 